\title{
Pengembangan Model Garden-Based Learning Meningkatkan Perilaku Prososial Anak usia dini
}

\author{
Danang Hardiansyah ${ }^{1 凶}$, Arif Rohman', Ellia Deviyanti ${ }^{3}$ \\ Pendidikan Anak Usia Dini, Universitas Negeri Yogyakarta, Indonesia ${ }^{(1)}$ \\ Sekolah Dasar Negeri 9 Punduh Pedada, Pesawaran(2) \\ DOI: $\underline{10.31004 / o b s e s i . v 6 i 3.1728}$
}

\begin{abstract}
Abstrak
Perilaku sosial anak seharusnya dikembangkan sejak dini. Penelitian ini bertujuan untuk mengetahui ada atau tidaknya peningkatan dalam pengembangan model garden-based learning untuk meningkatkan perilaku prososial anak usia dini. Jenis penelitian ini adalah penelitian dan pengembangan yang mengadaptasi model ADDIE, dengan subjek penelitian sebanyak 33 anak usia 5-6 tahun. Analisis data yang digunakan adalah uji nonparametric dan uji Wilcoxon Signed Rank. Hasil penelitian ini menunjukan negative ranks antara hasil pretest dan posttest adalah 0, nilai ini menunjukan tidak adanya penurunan nilai pretest ke posttest. Positif ranks antara hasil pretest dan posttest mengalami peningkatan, mean rank tersebut adalah 17.00 , nilai Ties 0 maka tidak adanya nilai yang sama antara pretest dan posttest. Diketahui Asymp.sig (2.tailed) bernilai 0.000 , hipotesis diterima karena nilai $0.000<0.05$, artinya ada perbedaan nilai pretest dan posttest, disimpulkan pengembangan model garden-based learning mampu meningkatkan perilaku prososial anak usia dini.
\end{abstract}

Kata kunci: pembelajaran berbasis kebun; kompetensi perilaku prososial; anak usia dini

\begin{abstract}
Children's social behavior should be developed from an early. This study aims to determine whether or there's not an increase in the development of garden-based learning models to improve prosocial behavior in early childhood. The type of research is, research and development that adapts the ADDIE model, with the research subjects as many 33 children aged 5-6 years. Data analysis used was nonparametric test and Wilcoxon Signed Rank test. The results of this study show that the negative ranks between the results of the pretest and posttest are 0 , this value indicates that there is no decrease in the value of pretest to posttest. The positive ranks between the pretest and posttest results have increased, the mean rank is 17.00, Ties value of 0 so it can be said that there is no equal value between pretest and posttest. It is known that Asymp.sig (2.tailed) is worth 0.000, the hypothesis is accepted because the value is $0.000<0.05$, meaning that there is a difference in the pretest and posttest scores, it can be concluded that the development of a garden-based learning model can improve prosocial behavior in early childhood
\end{abstract}

Keywords: garden-based learning; prosocial behavior competence; early childhood children

Copyright (c) 2021 Danang Hardiansyah, et al.

$\triangle$ Corresponding author:

Email Address: dananghardiansyah.2017@student.uny.ac.id (Yogyakarta, Indonesia)

Received 7 May 2021, Accepted 19 September 2021, Published 7 October 2021 


\section{PENDAHULUAN}

Pendidikan anak usia dini (PAUD) merupakan pendidikan yang bisa menciptakan peserta didik untuk tumbuh serta berkembang, bersosialisasi dengan lingkungan baik lingkungan keluarga maupun lingkungan masyarakat. Dimana Anak usia dini ialah manusia yang sedang mengalami proses pertumbuhan dan perkembangan yang begitu cepat, dapat juga sebagai anak yang memiliki masa peka. Dikatakan masa peka karena masa yang tepat untuk memondasikan anak dalam mengembangkan berbagai potensi dan kemampuan kognitif, bahasa, agama, fisik, sosial-emosional, dan seni (Mulyasa, 2012:16). Standar tingkat pencapaian perkembangan anak merupakan acuan untuk mengembangkan standi isi, proses, penilaian, serta pembiayaan dalam pengelolaan dan penyelenggaraan pendidikan anak usia dini.

Dari standar pencapaian itu maka akan dikelolanya pembelajaran yang menarik, efektif serta efesien karena membutuhkan bahan ajar yang inovatif. Seperti halnya pembelajaran berbasis kebun atau Garden-Based Lerning (GBL) dimana menjadikan kebun sebagai media pendidikan, pembelajaran yang baik untuk anak dank arena kebun juga begitu strategis untuk belajar anak. Pentingnya perilaku prososial ditumbuhkan pada anak sejak dini melalui pembelajaran yang sesuai, sehingga kepedulian terhadap lingkungan sekitar dan alam akan semakin melekat dalam diri anak sampai dewasa. Seperti yang dijelaskan oleh Iskandar (2013:213) yaitu menyampaikan materi pembelajaran lingkungan dapat diberikan sejak anak usia dini seperti di lingkungan pendidikan anak usia dini. Pendapat lainnya yaitu Johnson ( 2014:129) mengatakan bahwa lingkungan anak usia dini yang berkwalitas di luar ruangan tidak hanya berfungsi sebagai tempat mengeluarkan energy, emosi, tenaga melainkan mencakup unsur-unsur untuk menarik alam liar supaya memberikan pengalaman bagi anak untuk bekerja dengan tekstur dan alat-alat yang asli (nyata).

Fungsi pendidikan bagi anak usia dini antara lain mengenalkan anak dengan dunia sekitar seperti mengadakan kunjungan kekebun pertanian, ke kandang peternakan dengan tujuan sebagai mengenal bermacam-macam ciptaan Tuhan Yang Maha Esa dan juga mengenal jenis tanaman dan hewan serta perbedaan udara (Mursid, 2015:18). Maksudnya yaitu kebun atau taman dapat dijadikan sebagai tempat belajar untuk mengenal berbagai macam tanaman dan seluruh isi di kebun tersebut untuk meningkatkan perilaku prososial anak. Nelson dan Shaw (Cramer \& Ball, 2019:37) mengatakan bahwa halaman sekolah sebagai solusi untuk tantangan umum sebagai pendidik kelas, dan kukurangan waktu untuk menciptakan peluang ini yaitu dengan pembelajaran luar ruangan yang difasilitasi seperti mengembangkan komitment terhadap pengetahuan lingkungan.

Berkebun itu dapat meningkatkan kompleksitas atau menggabungkan adaptasi dari luar sekolah maupun dalam sekolah seperti lingkungan belajar, dalam praktik berkebun seperti yang dijelaskan oleh O'Donnel dan Sims (Verde \& Valdés, 2014:253) dengan praktik yang baik dapat berpartisipasi dalam lingkungan belajar yang berbeda. Pembelajaran ini dapat memneuhi semua karakteristik praktik yang baik dimana dapat menjangkau anak-anak yang tidak terlibat sekalipun, menurut Skinner (Verde \& Valdés, 2014:254) dengan bantuan kurikulum yang disesuaikan dengan minat peserta didik, seperti berpartisipasi menjadikan peserta didik terlibat langsung dalam kegiatan di kebun, kemudian lingkungan belajar menjadi hijau dan sejuk. Padahal ada jargon sekolah "go green", kenyataanya di lapangan ada sekolah-sekolah yang tidak memiliki lahan atau taman yang terbatas. Anak merupakan generasi penerus suatu bangsa yang membutuhkan perhatian khusus untuk tumbuh dan berkembang. Setiap anak itu berbeda-beda baik sikap, sifat maupun fisiknya.

Blair (Groenfeldt, 2016:13) mengatakan bahwa pembelajaran berbasis kebun dan pembelajaran berbasis tempat itu berjalan seiring sekolah dan program pemuda berusaha untuk mengatasi dinamika masyarakat melalui peluang pendidikan yang membahan lahan local, system pangan, dan lingkungan alami. Seperti penjelasan dari Williams \& Dixon (2013:213) pembelajaran yang mencakup program, kegiatan dan proyek dimana kebun atau taman adalah fondasi untuk pembelajaran terintegrasi dalam dan lintas disiplin ilmu melalui 
pengalaman dunia nyata. Berbagai pendapat tersebut menjelaskan bahwa pembelajaran berbasis kebun merupakan pemanfaatan kebun sebagai alat pembelajaran dimana anak-anak beraktifitas langsung dengan melakukan kegiatan menyiapkan media tanam, menanam, merawat maupun memanen sehingga memberikan pengalaman kepada anak-anak untuk melek ekologi dan kesadaran lingkungan yang harus dibangun sejak usia dini dimana nantinya akan mengerti tentang menjaga alam yang ada.

Kemudian dari itu pula bahwa tujuan dari pembelajaran berbasis kebun ini mempelajari nilai-nilai budaya dan sosial yang terkait dengan kesadaran ekologis dan mengembangkan serta meningkatkan ketrampilan otentik di dunia nyata (Vandermaas-peeler \& Mcclain, 2015:9). Karena pembelajaran di kebun juga meningkatkan pengetahuan tentang siklus hidup tanaman dan meningkatkan aspek perkembangan sosial emosional anak. Perkembangan sosial adalah proses pemerolehan kemampuan anak untuk berprilaku yang sesuai dengan keinginanya yang berasal dari dalam individu anak dengan tuntunan dan sosial yang berlaku dimasyaraka. Dengan kegiatan berkebun anak-anak akan dilatih untuk memiliki sikap tanggung jawab dan cinta alam (Meriyana, 2013:127). Knight \& Carlo (2012:3) menyatakan bahwa nilai-nilai dalam kekeluragaan itu terkait secara positif dengan perilaku pengasuhan yang mempromosikan perilaku prososial itu. Bahkan Callaghan \& Corbit (2018:7) pun mengatakan bahwa keragaman budaya dalam berperilaku setia anak atau individu itu akan menjadi jelas ketika masa kecil menengah

Suyadi (Drupadi \& Syafrudin, 2019:91) menyatakan bahwa perkembangan sosial adalah tingkat jalinan interaksi anak dengan orang lain seperti dari orang tua, saudara, keluarga, teman bermain, pendidik serta masyarakat. Orang tua dan pendidik ingin peserta anaknya menjadi manusia yang memiliki perilaku murah hati, empati, bertanggung jawab, dan dapat bekerja sama. Perilaku prososial ialah tindakan untuk memberikan manfaat kepada orang lain, seperti menunjukan kepedulian terhadap orang lain tanpa meminta imbalan dalam bentuk apapun, tindakan sukarela untuk membantu, berbagi, menolonh, jujur dan kerjasama yang ditunjukan dengan perilakunya (Matondang, 2016:37) dan (Newton et al, 2014:1). Perilaku prososial mulai berkemban sejak anak masih bayi menurut (Williams et al, 2015:16) proses pembentukan perilaku prososial khususnya empati diawali dari bayi baru lahir, dimana bayi menanggapi tangisan saat lahir dengan reaksi tangisanya sendiri dan ketika memasuka usia balita anak akan merespon dengan empati yang ditunjukan seperti memberikan pelukan pada teman.

Hasil survey yang dilakukan oleh Restuwati (2012:20-21) terhadap 320 pendidik dari 79 taman kanak-kanak di kabupaten Sleman menunjukan bahwa $91 \%$ pendidik menyatakan bahwa perilaku agresif dilingkungan peserta didik prasekolah masih banyak terjadi. Perilaku agresif verbal ini ditunjukan dengan menertawai teman ditemukan sebanyak $83,44 \%$, mengatakan hal yang buruk pada teman $32.45 \%$ dan mendiamkan teman sebanyak $13.25 \%$. perilaku agresif yang dihubungkan dengan kepemilikan barang ditunjukan dalam perilaku tersebut merebut barang atau mengambil barang milik teman sebanyak 35.1\%, merusak barang teman sebanyak $15.6 \%$ dan menyembunyikan barang milik teman sebanyak $55.3 \%$.

Hasil observasi dan wawancara di Taman Kanak-kanak (TK) yang berada di Kecamatan Airnaningan 11 September 2019 diperoleh pengamatan bahwa kegiatan berkebun itu sangat begitu menyenangkan untuk pendidik maupun peserta didik. Karena anak dapat mengenal, mengetahui proses dari penanaman sampai panen, karena dengan bercocok tanam tadi anak dapat menanam, merawat serta memanen secara langsung. Selain itu tidak ada salahnya bila tiap sekolah memiliki kebun atau taman untuk kegiatan belajar. Masih dalam tahap wawancara juga diperoleh data bahwa perilaku prososial anak sudah mulai tampak, tetapi masih ada pula yang belum, yang terlihat pada beberapa anak yaitu dimana adanya anak yang menghampiri temannya yang sedang menangis, kemudian membantu dan beberapa anak sedang berbagi bekal dengan temannya mapun bermain bersama. Bila dikebun, anak-anak ada yang membantu menyiram dengan mengangkat bersama gembor. 
Berdasarkan hasil penelitian sebelumnya bahwa banyak sekali peneliti yang membahas tentang pembelajaran berbasis kebun untuk meningkatkan kecerdasan natural dan sebagainya. Padahal pembelajaran berbasis kebun ini memenuhi semua karakteristik praktik yang baik untuk menjangkau anak usia dini, karena kegiatan ini begitu bermakna dan nyata serta sesuai dengan kurikulum. Maka dapat diambil kesimpulan bahwa model pembelajaran berbasis kebun dapat digunakan sebagai model pembelajaran dalam meningkatkan kompetensi perilaku prososial anak pada taman kanak-kanak, karena dalam berkebun itu membutuhkan kerjasama, tolong menolong. Permasalahan yang dihadapi ada beberapa sekolah tidak adanya kesedian kebun atau taman yang luas untuk melakukan bercocok tanam. Bertujuan pula untuk menjaga lingkungan alam sekitar dan ecolitracy. Dengan anak menggunakan tangan mereka untuk melakukan kegiatan bermanfaat untuk teman, keluarga, masyarakat dan lingkungan alam sekitar.

Beberapa permasalahan prososial yang ditemukan peneliti berdasarkan observasi di tk Aisyiyah Bustanul Athfal yang berjumlah 33 peserta didik dari 2 kelas menunjukan ketika kegiatan berkebun ada beberapa anak yang tidak mau berbagi, bekerja sama dalam pembelajaran itu. Oleh karena itu penulis tertarik untuk mengkajinya dalam model pembelajaran berbasis kebun untuk meningkatkan perilaku prososial anak usia dini usia 5-6 tahun.

\section{METEDOLOGI}

Penelitan dan pengembangan ini dilakukan pada tanggal 11 September 2019 di TK Aisyiyah Bustanul Athfal, dengan jumlah populasi dalam penelitian ini yaitu 33 peserta didik kelas B dan penelitian ini menggunakan model ADDIE yang terdiri dari lima tahapan yaitu: (1) analyze, (2) design, (3) develop, (4) implement, (5) evaluation yang dikembangkan oleh Robert Maribe Branch (Sugiyono, 2019:765). Ialah sebagai konsep pengembangan produk yang dimana konsep ini sedang diterapkan untuk membangun pembelajaran berbasis kinerja, dengan pembelajaran yang berpusat pada peserta didik.

Berdasarkan hasil wawancara dan observasi di TK Aisyiyah Airnaningan bahwa umumnya kegiatan yang berkaitan dengan perilaku prososial dilakukan melalui bermain, atau dengan kegiatan tidak sengaja, model pembelajaran yang berkaitan berkebun sulit dilakukan dengan perilaku prososial anak dengan demikian pembelajaran lebih condong kearah calistung maupun mewarnai. Hasil dari analisis itu kemudian dapat digunakan sebagai pedoman untuk mengembangkan model pembelajaran berbasis kebun untuk meningkatkan kompetensi perilaku prososial anak. Pada penelitian ini, uji coba produk digunakan untuk menguji kelayakan dan keefektifan pengembangan model pembelajaran berbasis kebun pada anak, sebelumnya uji kelayakan ini divalidasikan terlebih dahulu kepada ahli media dengan nilai 96, ahli materi dengan nilai 84 dan dengan dua praktisi (pendidik) dengan nilai 88 dan nilai 90. Dapat dilihat pada bagan skema penelitian pada gambar 1.

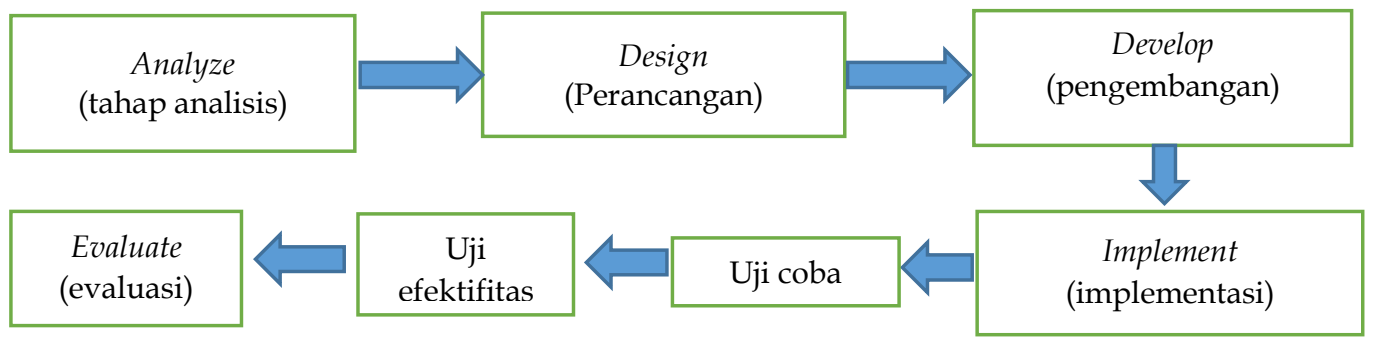

\section{Gambar 1. Tahap pengembangan pembelajaran berbasis kebun untuk meningkatkan} kompetensi dengan model ADDIE

Subjek penelitian ini adalah peserta didik Taman Kanak-kanak yang berasal dari Taman Kanak-kanak Asiyah Bustanul Athafal. Menggunakan satu sekolah dan dua kelas B. 
Penelitian ini memfokuskan pada anak usia 5-6 tahun, menggunakan uji pretest dan uji posttest dimana semuanya dilakukan di 2 kelas B. jumlah subjeknya yaitu 33 anak di TK ABA. Pengumpulan data digunakan sebagai alat untuk mengukur sebuah penelitian, tekhnik yang dipakai pada penelitian ini adalah penggumpulan data dengan angket validasi dan observasi, serta unjuk kerja hal ini dilakukan untuk mengetahui perilaku prososial anak. Pada uji efektifitas menggunakan uji $\mathrm{t}$ dependent dan uji wilcoxon, pada uji efektifitas dilaksanakan dengan uji nonparametric. Syarat diterimanya yaitu Ho sebagai sebaran berdistribusi normal atau Ha sebagai sebaran data berdistribusi tidak normal.

\section{HASIL DAN PEMBAHASAN}

Gambar kegiatan tentang model pembelajaran berbasis kebun untuk meningkatkan perilaku prososial anak usia dini,
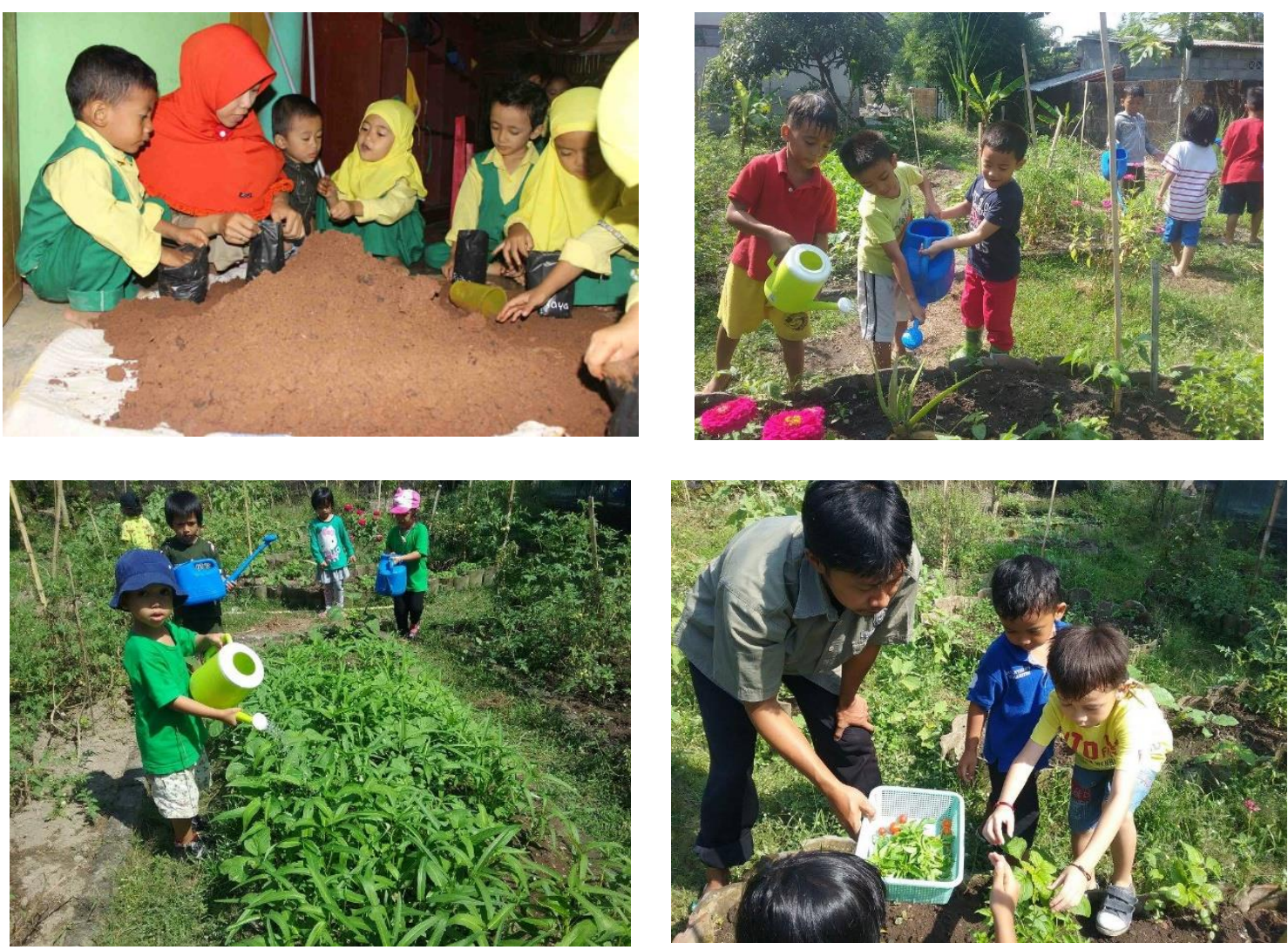

Gambar 1. Kegiatan berkebun dengan perilaku prososial

Gambar 1 menunjukan kegiatan pembelajaran anak selama di kelas dan di kebun atau di luar ruangan, pendidik memberikan beberapa kegiatan yang dapat dilaksanakan oleh peserta didik dalam satu hari atau dengan sesuai jadwal. Hasil penelitian adalah hasil gambaran yang di dapat untuk mendukung hasil penelitian, data pada penelitian didapat melalui observasi kemudian angket validasi dan wawancara. Hasil dari penelitian pengembang ini yaitu model pembelajaran berbasis kebun yang dikemas dalam bentuk buku panduan dimana buku ini sebagai pegangan pendidik untuk melakukan kegiatan berkebun saja. Berikut adalah hasil dari kelayakan (validasi) dan hasil uji coba produk.

Hasil penelitian dan pengembangan pada kelayakan model pembelajaran berbasis kebun oleh validasi ahli media oleh Dr. Puji Yanti, M.Pd., dan alhi materi oleh Dr. Amir Syamsudin, S.Ag., M.Ag. 
Pengembangan Model Garden-Based Learning Meningkatkan Perilaku Prososial Anak usia dini DOI: $10.31004 /$ obsesi.v6i3.1728

Tabel 1. Hasil Validasi Ahli Media dan Ahli Materi

\begin{tabular}{llclll}
\hline No & \multicolumn{1}{c}{ Nama } & $\begin{array}{c}\text { Skor } \\
(\mathbf{X})\end{array}$ & $\begin{array}{c}\text { Skor } \\
\text { Minimum }\end{array}$ & $\begin{array}{c}\text { Skor } \\
\text { Maksimum }\end{array}$ & Kategori \\
\hline 1 & $\begin{array}{l}\text { Dr. Amir } \\
\text { Syamsudin,S.Ag;M.Ag }\end{array}$ & 84 & 21 & 84 & $\begin{array}{l}\text { Sangat } \\
\text { baik }\end{array}$ \\
2 & Dr.Puji Yanti, M.Pd & 96 & 26 & 104 & Baik \\
\hline
\end{tabular}

Tabel 2. Hasil Validasi Praktisi (Pendidik)

\begin{tabular}{llcccc}
\hline No & Nama & $\begin{array}{c}\text { Skor } \\
(\mathbf{X})\end{array}$ & $\begin{array}{c}\text { Skor } \\
\text { Minimum }\end{array}$ & $\begin{array}{c}\text { Skor } \\
\text { Maksimum }\end{array}$ & Kategori \\
\hline 1 & Vivi Martiniyati,S.Pd.Gr & 88 & 24 & 104 & Sangat baik \\
2 & Nur Asyiah,S.Pd.AUD & 90 & 24 & 104 & Sangat baik \\
\hline
\end{tabular}

Menurut hasil validasi pada tabel 2. dilihat bahwa produk yang dikembangkan dinyatakan baik dan cukup untuk diujicobakan. Hasil dari penelitian dan pengembangan untuk keterlaksanaan pembelajaran ini terdapat pada ujicoba di lapangan.

Tabel. 3 Data Hasil Pretest dan Posttes

\begin{tabular}{lcccc}
\hline \multirow{1}{*}{ Hasil } & \multicolumn{3}{c}{ Kompetensi perilaku prososial } \\
& B1 & Pre-test & Post-test & B2 \\
\hline Jumlah anak & 16 & 17 & 16 & 17 \\
Nilai maksimum & 30 & 33 & 48 & 51 \\
Nilai minimum & 24 & 24 & 44 & 47 \\
Jumlah skor & $\mathbf{4 2 0}$ & $\mathbf{5 1 0}$ & $\mathbf{7 3 3}$ & $\mathbf{8 2 2}$ \\
\hline
\end{tabular}

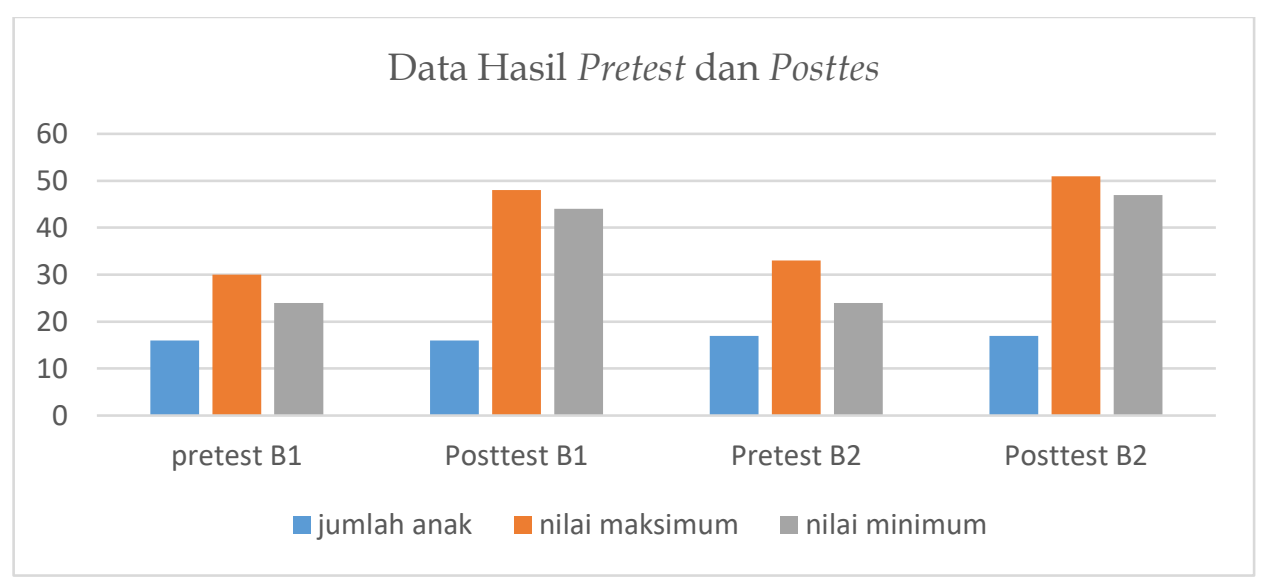

Gambar 2. data Pretest dan posttest kedua kelas B.

Gambar 2 menunjukan bahwa, pembelajaran berbasis kebun untuk meningkatkan perilaku prososial anak menunjukan hasil peningkatan dengan jumlah anak ditiap kelas berbeda. Di hitung secara keseluruhan dari jumlah anak yang ada dan dilihat pula dalam nilai minimum dan maksimum. dimana hasil nilai untuk anak kelas B1 yang berjumlah 16 anak dengan saat pretest nilai maksimum yaitu 30 dan nilai minimum 24 , kemudian untuk hasil posttest kelas B1 dengan nilai maksimum 48 dan nilai minimum 44 . Sedangkan untuk kelas B2 dengan jumlah 17 anak, nilai prestest maksimum 33 dan nilai minimum 24, dan nilai untuk hasil posttest maksimum 51 dan nilai minimum 47. Maka dapat dikatakan adanya peningkatan. 
Tabel. 4 Data Dari Konversi Pretest dan Posttest Kompetensi Perilaku Prososial

\begin{tabular}{ccc}
\hline Hasil & $\begin{array}{c}\text { Kompetensi perilaku prososial } \\
\text { Kelas B1 } \\
\text { Kelas B2 } \\
\text { Pretest dan posttest }\end{array}$ & $\begin{array}{c}\text { Pertest dan posttest } \\
\text { Pe.15 }\end{array}$ \\
\hline 1 & 51.72 & 68.97 \\
2 & 66.67 & 70.00 \\
3 & 50.00 & 78.57 \\
4 & 91.67 & 58.62 \\
5 & 84.00 & 75.00 \\
6 & 76.92 & 80.77 \\
7 & 87.50 & 87.50 \\
8 & 76.92 & 46.88 \\
9 & 92.00 & 48.48 \\
10 & 91.67 & 45.45 \\
11 & 62.07 & 44.12 \\
12 & 67.86 & 53.13 \\
13 & 73.08 & 51.61 \\
14 & 91.67 & 48.48 \\
15 & 76.00 & 51.61 \\
16 & 67.86 & 58.06 \\
17 & & 17 \\
Jumlah anak & 16 & 62.5537 \\
Nilai rata-rata & 75.4748 & 96.15 \\
Nilai maksimum & 92.00 & 44.12 \\
Nilai minimum & 50.00 & \\
\hline
\end{tabular}

Pada tabel 3 dan tabel 4 dapat dilihat dimana data pada kegiatan, tabel 3 ini dapat dilihat hasil pretest dan posttes setiap kelas, bahwa nilai posttest anak di kedua kelas mengalami peningkatan dibanding dengan nilai pretest, dengan adanya data dari tabel 3 lalu mencari nilai nonparametric dan nilai uji Wilcoxon untuk menentukan baik dan keefektifan produk model pembelajaran berbasis kebun yang telah dikembangkan dan dikonversikan nilainya 0-100. Dan tabel 4 itu hasil dari konversi dengan bantuan SPSS versi 22, dapat diperoleh hasil nilai minimum dari pretest dan posttest untuk kelas B1 sebesar 50.00 sedangkan untuk nilai maksimum ialah 92.00. kemudian untuk kelas B2 dengan nilai minimum adalah 44.12 dan nilai maksimumnya 96.15 .

Tabel 5. Kategori tafsiran keefektifan

\begin{tabular}{cc}
\hline Nilai tafsiran keefektifan & Kategori \\
\hline$<40$ & Tidak efektif \\
$40-55$ & Kurang efektif \\
$56-75$ & Cukup efektif \\
$>76$ & Efektif \\
\hline
\end{tabular}

(Meltzer, 2002)

Tabel 5 berguna untuk melihat keefektifan data pada tabel 4, dengan pedoman di tabel 5 ini maka dapat dilihat keefektifannya produk tersebut, kemudian di perjelas dengan menggunakan diagram sebagaimana pada gambar 3.

Berdasarkan tabel 4, tabel 5, dan gambar diagram lingkaran di atas memiliki keterkaitan untuk ketepatam melihat tentang produk yang akan dikembangkan itu efektif atau tidak, diagram menyebutkan bahwa efektif dimana nilai lebih dari 76 sebesar $40 \%$, sedangan nilai cukup efektif dan kurang efektif sebesar 30\%. Hal ini menggambarkan bahwa produk layak untuk digunakan. Hasil yang didapat dari kedua kelas tersebut pada produk 
model pembelajaran berbasis kenun secara keseluruhan adalah 92.00 untuk kelas B1 dan 96.15 untuk kelas B2.

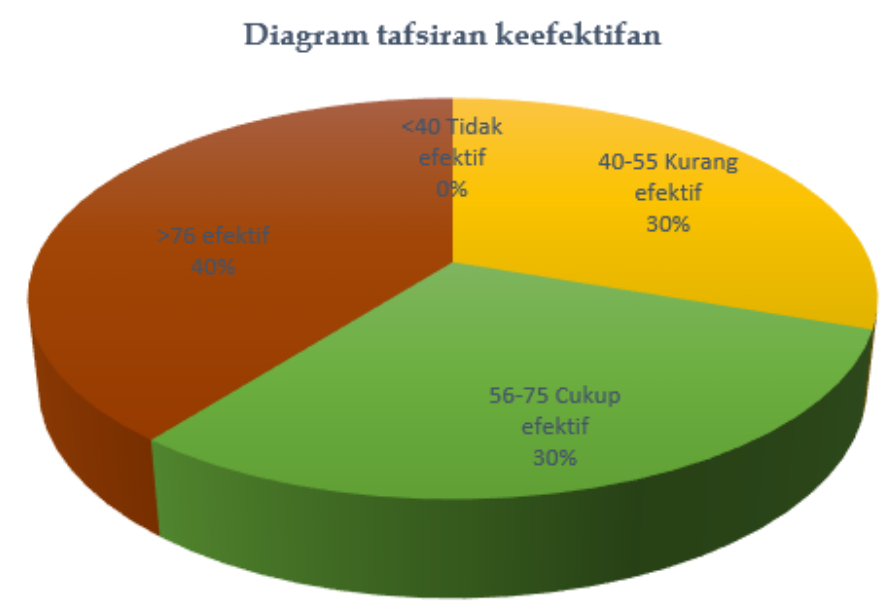

घ<40 Tidak efektif $\square$ 40-55 Kurang efektif $\square$ 56-75 Cukup efektif $\mathbf{0}>76$ efektif

\section{Gambar 3. Produk Efektif Untuk Pembelajaran Berbasis Kebun}

Kemudian pengujian pula dilakukan dengan menggunakan uji nonparametrik untuk mengetahui besaran data yang diperoleh berdistribusi normal atau tidak. Data yang digunakan menggunakan data pretest dan posttes perilaku prososial. Data dikatakan berdistribusi normal apabila taraf signifikasi yang diperoleh lebih besar dari 0.05 , uji coba ini menggunakan uji Wilcoxon dengan bantuan program SPSS versi 22 for windows. Karena merupakan salah satu cara menentukan kenormalan suatu data yang jumlahnya di bawah 50 sampel. Adapun hipotesis yang dirumuskan adalah sebagai berikut: Ho sebagai sebaran data berdistribusi normal dan $\mathrm{Ha}$ sebagai sebaran data tidak berdistribusi normal.

Tabel 6. Hasil Uji Nonparametrik menggunakan wilcoxon

\begin{tabular}{|ll|r|r|r|}
\hline & \multicolumn{1}{c|}{ R } & Mean Rank & Sum of Ranks \\
\hline posttest - pretest & Negative Ranks & $0^{\mathrm{a}}$ & .00 & .00 \\
& Positive Ranks & $33^{\mathrm{b}}$ & 17.00 & 561.00 \\
& Ties & $0 \mathrm{c}$ & & \\
& Total & 33 & & \\
\hline a. posttest < pretest & & & \\
b. posttest > pretest \\
c. posttest $=$ pretest
\end{tabular}

Berdasarkan data tabel 6 maka dapat dijelaskan bahwa negative ranks atau selisih antara hasil pretest dan posttest adalah 0 (nol), baik itu pada nilai $(\mathrm{N})$, mean rank, maupun sum of rank. Nilai ini menunjukkan tidak adanya pengurangan dari nilai pretest ke nilai posttest. Kemudian positif rank atau selisih antra pretest dan posttest, dimana terdapat 33 data positif (N) yang artinya nilai pretest dan nilai posttest ata rata-rata peningkatan adalah sebesar 17,00 . Sedangan jumlah rangking positif atau sum of ranks adalah sebesar 561,00. Ties adalah kesamaan nilai pretest dan posttest dapat dilihat bahwa nilai Ties adalah 0 (nol) maka dapat di katakana bahwa tidak ada nilai yang sama antara pretest dan posttes, dan dapat di ambil kesimpulan bahwa jika nilai Asymp sig <0.05, maka hipotesis diterima dan jika nilai Asymp sig $>0,05$ maka hipotesis di tolak. 
Setelah dilakukan uji nonparametric dan data yang dihasilkan berdistribusi normal, maka dapat dilakukan uji Wilcoxon pada tabel 7.

Tabel 7. Hasil uji statistic uji wilcoxon

Test Statistics ${ }^{a}$

\begin{tabular}{|l|r|}
\hline & posttest - pretest \\
\hline$Z$ & $-5.021^{\mathrm{b}}$ \\
Asymp. Sig. (2-tailed) & .000 \\
\hline
\end{tabular}

a. Wilcoxon Signed Ranks Test

$b$. Based on negative ranks.

Berdasarkan tabel 7. di atas maka dapat dilihat secara ringkas hasil statistic deskriptif berdasarkan output "test statistic" dapat diketahui bahwa nilai asymp.sig (2-tailed) bernilai 0.000, karena nilai 0.000 lebih kecil dari $<0.05$ maka dapat disimpulkan bahwa "hipoteis diterima", artinya adanya perbedaan antara hasil pretest dan posttest. Sehingga dapat disimpulkan bahwa "ada pengaruh penggunaan model pembelajaranberbasis kebun untuk meningkatkan perilaku prososial anak usia dini".

Untuk dapat diketahui tentang perilaku prososial yaitu ketertarikan yang tidak egois dalam membantu orang lain, perbuatan manusia dalam bentuk alturisme itu sangat banyak dan intinya untuk membantu orang lain. Perilaku membantu orang lain itu seperti: berbagi, peduli, menghibur dan menolong (Caprara dkk, 2012). Perkembangan sosial memberikan tugas kepada seorang anak untuk dapat menunjukan perilaku prososial, perkembangan awal anak ini mulai dari membantu bahan berbagi ang merupakan ketrampilan penting membangun hubungan sosial yang positif di hari esok (Spinrad et al., 2007). Pembelajaran yang menarik, efektif dan efisien tentunya membutuhkan bahan ajar yang inovatif pula. Untuk itu pendidik yang professional dituntut kreativititas untuk mampu menyusun bahan ajar yang inovatif, menarik, kontekstual dan sesuai dengan kebutuhan peserta didik.

Pembelajaran berbasis kebun dapat didefinisikan sebagai strategi pembelajaran yang memanfaatkan taman, kebun atau lahan sebagai alat pengajaran Daniel Desmond \& Subramaniam (2004). Pembelajaran ini sebagai media pendidikan, pembelajaran yang baik untuk anak, karena kebun atau taman begitu strategis untuk belajar anak. Seperti yang diungkapkan oleh Herd tentang taman ialah tempat yang sangat menarik dan mengasyikan dimana peserta didik dapat bermain, belajar, dan bekerja (Skelly \& Bradley, 2007). Pengembangan pendidikan berbasis kebun secara bersamaan diperkuat oleh bangkitnya pendidikan kebun nasional dan gerakan sekolah hijau. Dimana Blair mengatakan bahwa pembelajaran berbasis kebun dan pembelajaran berbasis tempat itu seiring berjalannya waktu sekolah dan progam pemuda berusaha untuk mengatasi dinamika masyakakat melalui peluang pendidikan yang membahasa lahan local, system pangan, dan lingkungan alami (Groenfeldt, 2016).

Penelitian sebelumnya menunjukan pentingnya program ini dalam mempromosikan pemahaman sosial dan lingkungan dengan pendekatan pendidikan yang lebih aktif dan langsung dimana dalam mengevakluasi dampak dari program ini seperti yang Pendapat tersebut menggambarkan tentang program berkebun antara setiap sekolah berbeda, tetapi semuanya memiliki kegiatan pembelajaran dan pengalaman yang diajarkan serta didapat dalam lingkungan.

Williams dan Dixon (2013) mengatakan bahwa pembelajaran berbasis kebun itu mencakup program, kegiatan, dan proyek dimana taman adalah fondasi untuk pembelajaran terintegrasi dalam dan lintas disiplin ilmu melalui pengalaman dunia nyata yang aktif serta menarik. Pembelajaran yang menekankan pada proses pembelajaran nyata, materi pembelajaran secara langsung melalui kegiatan pembelajaran dengan materi belajar secara langsung ini peserta didik diharapkan dapat tambahan ingatanya, mengevaluasi dan selanjutnya menentukan tujuan yang akan dicapai. Knapp pun mengatakan bahwa 
lingkungan yang menghasilkan warga yang melek lingkungan dan bertanggung jawab (Fisher dkk 2015). Penjelasan Dahlia (2014) dengan membawa peseta didik ke kebun sekolah dan bercocok tanam, seperti menanam bawang, sawi disitu anak diajarkan untuk memelihara tanaman dengan menyiram, menyiangi, dan memupuk serta jadi anak pula yang memanennya.

Einsberg, spinrad, dan knafonoam berkata bahwa perilaku prososial yaitu sebagai perilaku sukarela yang dimaksudkan untuk bermanfaat bagi kebutuhan orang lain (Spingrad TL \& Gal D.E, 2017). Perkembangan perilaku yang sering muncul pada usia 5-6 tahun di dalam bersosialisasi dengan teman sebaya tentang sikap saling berbagi dengan teman-teman, gembira bersama, dan bersenang dengan cara bermain. Begitupula dengan emosionalnya, responya bisa dikatan bagus apabila ada ataupun tidak kepada orang lain, yak arena dengan adanya beberapa keadaan, perilaku prosoial akan disertai oleh masalah emosional juga (Hay \& Pawlby, 2003). Anak yang secara sosial aktif, bekerja sama dan ramah akan baik dalam aspek sosial dan akademik serta memiliki resiliesi yang baik pula. Knight \& Carlo (2012:3) menyatakan bahwa nilai-nilai dalam kekeluragaan itu terkait secara positif dengan perilaku pengasuhan yang mempromosikan perilaku prososial itu. Bahkan Callaghan \& Corbit (2018:7) pun mengatakan bahwa keragaman budaya dalam berperilaku setia anak atau individu itu akan menjadi jelas ketika masa kecil menengah

Tidak hanya itu menurut Poorthuis et al. ( 2012) bahwa peserta didik akan cendrung menampikan perilaku prososial kepada anak yang dekat denganya maupum yang mereka kenak seperti teman bermain. Miller (2007) mengatakan bahwa kegiatan yang melibatkan anak-anak di luar kelas begitu banyak manfaat yang dimiliki oleh anak dengan pengalaman positif, rasa kagum, imajinasi, kreatifitas, ketrampilan pengamatan, ketrampilan hubungan, motivasi belajar dan pentingannya memperkenalkan pengalaman berkebun. Piek dkk, (2008) mengatakan bahwa pembelajaran berbasis kebun lebih berfokus pada sains dan nilai tes peserta didik meningkat secara signifikasi setelah mereka mengikuti pembelajaran di sekolah. Sedangkan dari segi kompetensi sosial Rose-Krasnor dkk, (1996) mendefinisikan bahwa kemampuan untuk mencapai keinginan dalam berinteraksi sosial dengan menjaga hubungan positif dengan orang lain dalam berbagai situasi, jadi peserta didik diajarkan untuk selalu baik kepada semua orang dan diterima dengan teman sebaya.

Model pembelajaran berbasis kebun yang dikembangkan ini layak digunakan dalam proses pembelajaran untuk meningkatkan kompetensi perilaku prososial anak, dengan adanya bukti dari hasil validasi yang dilakukan oleh ahli materi, ahli media maupun pendidik. Dengan keriteria baik dan layak yaitu nilai 84 ahli materi, dan 96 ahli media. Keefektifan dengan melibatkan 2 kelas yaitu nilai rata-rata skor untuk kelas B1 $=75.5 \%$, sedangkan untuk nilai rata-rata kelas B2 62.6\% yang hasil dari kedua kelas itu cukup efektif. Dapat diketahui bahwa nilai asymp.sig (2-tailed) bernilai 0.000, karena nilai 0.000 lebih kecil dari $<0.05$ maka dapat disimpulkan bahwa "hipoteis diterima", artinya adanya perbedaan antara hasil pretest dan posttest. Sehingga dapat disimpulkan bahwa "ada pengaruh penggunaan model pembelajaran berbasis kebun untuk meningkatkan perilaku prososial anak usia dini".pada model pembelajaran berbasis kebun sehingga dapat berpengaruh terhadap kompetensi perilaku prososial anak secara signifikan. Maka dapat disimpukan bahwa model pembelajaran berbasis kebun cukup efektif terhadap kompetensi perilaku prososial anak usia 5-6 tahun.

\section{SIMPULAN}

Pengembangan model pembelajaran berbasis kebun berpengaruh dan cukup efektif digunakan untuk meningkatkan kompetensi perilaku prososial pada anak usia dini. Model ini merupakan pembelajaran yang baik untuk anak, karena kebun begitu strategis untuk belajar anak. Dengan demikian model ini dapat menjadi alternatif model pembelajaran untuk meningkatkan kemampuan perilaku sosial pada anak usia dini. 


\section{UCAPAN TERIMA KASIH}

Terima kasih peneliti ucapkan kepada orang tua, keluarga, dosen pembiming, validator ahli media, validator ahli materi dan pendidik di Taman Kanak-kanak Aisyiyah Airnaningan di kabupaten tanggamus lampung, serta pengelola jurnal obsesi yang telah memberikan kontribusinya, motivasi dalam pembuatan artikel ini.

\section{DAFTAR PUSTAKA}

Callaghan, T., \& Corbit, J. (2018). Early prosocial development across cultures. Current Opinion in Psychology, 20, 102-106. https:// doi.org/10.1016/j.copsyc.2017.07.039

Caprara, G. V., Alessandri, G., \& Eisenberg, N. (2012). Prosociality : The Contribution of Traits, Values, and Self-Efficacy Beliefs. 102(6), 1289-1303. https:// doi.org/10.1037/a0025626

Cramer, S. E., \& Ball, A. L. (2019). Wild Leaves on Narrow STEMs : Exploring Formal and Nonformal Education Tensions Through Garden-Based Learning. 60(4), 35-52. https://doi.org/10.5032/jae.2019.04035

Dahlia, S. dan. (2014). Implementasi dan Inovasi Kurikulum PAUD 2013. Bandung: PT. Remaja Rodakarya.

Daniel Desmond, J. G., \& Subramaniam, A. (2004). Revisiting garden-based learning in basic education. International Institute for Educational Planning: Food and Agriculture Organization of the United Nations.

Drupadi, R., \& Syafrudin, U. (2019). Hubungan Regulasi Emosi dengan Perilaku Prososial Anak Usia Dini. Aulad: Journal on Early Childhood, 2(3), 91-97. https:// doi.org/10.31004/aulad.v2i3.41

Fisher-maltese, C., \& Zimmerman, T. D. (2015). A Garden-Based Approach to Teaching Life Science Produces Shifts in Students ' Attitudes toward the Environment. 10(1), 51-66. https:// doi.org/10.12973/ijese.2015.230a

Groenfeldt, J. (2016). Garden-Based Learning in Worcester, Massachusetts: Addressing Science and Health Curriculum Gaps through Summer Youth Programming.

Gross, J. T., Cassidy, J., Stern, J. A., \& Brett, B. E. (2017). The multifaceted nature of prosocial behavior in children : Links with attachment theory and research. (December 2015), 118. https:// doi.org/10.1111/sode.12242

Hay, D. F., \& Pawlby, S. (2003). Prosocial Development in Relation to Children's and Mothers' Psychological Problems. Child Development, 74(5), 1314-1327. https:// doi.org/10.1111/1467-8624.00609

Iskandar, Z. (2013). Psikologi Lingkungan; Metode dan Aplikasi. Bandung: PT.Refika Aditama.

Johnson, K. (2014). Creative Connecting : Early Childhood Nature Journaling Sparks Wonder and Develops Ecological Literacy. 2(1), 126-139.

Knight, G. P., \& Carlo, G. (2012). Prosocial Development Among Mexican American Youth. Child Development Perspectives, 6(3), 258-263. https://doi.org/10.1111/j.17508606.2012.00233.x

Matondang, E. S. (2016). Perilaku Prososial (Prosocial Behavior) Anak Usia Dini dan Pengelolaan Kelas Melalui Pengelompokan Usia Rangkap (Multiage Grouping). Edu Humaniora:Jurnal Pendidikan Dasar Kampus Cibiru, 8(1), 34-47. https://doi.org/10.17509/eh.v8i1.5120

Meltzer. (2002). The relationship between mathematics preparation and conceptual learning gains in physics: a possible, hidden variable. in diagnostic pretest scores, department of physics and astronomy. Lowa State University, Annes, LowaJurnal Am.J.Physic, 50011. https:// doi.org/10.1119/1.1514215

Meriyana. (2013). Pengelolaan Lingkungan Belajar (Edisi Pert). JAKARTA: kencana prenada media group.

Miller, D. L. (2007). The Seeds of Learning : Young Children Develop Important Skills Through Their Gardening Activities at a Midwestern Early Education Program. Applied 
Environmental Education \& Communication, (October 2014), 37-41. https://doi.org/10.1080/15330150701318828

Mulyasa. (2012). Manajemen PAUD. Bandung: PT.Remaja Rosdakarya.

Mursid. (2015). Belajar dan Pembelajaran PAUD. Bandung: PT. Remaja Rosdakarya.

Newton, E. K., Laible, D., Carlo, G., Steele, J. S., \& McGinley, M. (2014). Do sensitive parents foster kind children, or vice versa? Bidirectional influences between children ' $\mathrm{s}$ prosocial behavior and parental sensitivity . Developmental Psychology, 50(6), 18081816. https:// doi.org/10.1037/a0036495

Piek, J. P., Dawson, L., Smith, L. M., \& Gasson, N. (2008). The role of early fine and gross motor development on later motor and cognitive ability. Human Movement Science, 27(5), 668-681. https:// doi.org/10.1016/j.humov.2007.11.002

Poorthuis, A. M. G., Thomaes, S., Denissen, J. J. A., Aken, M. A. G. Van, Orobio, B., \& Castro, D. (2012). Journal of Experimental Child Prosocial tendencies predict friendship quality , but not for popular children. Journal of Experimental Child Psychology, 112(4), 378388. https:/ / doi.org/10.1016/j.jecp.2012.04.002

Restuwati, E. S. (2012). Pengaruh Implementasi Program " Temanku Sahabatku " dalam Meningkatkan Perilaku Prososial Anak Pra Sekolah. 11, 19-31. https:// doi.org/10.26555/humanitas.v11i1.2324

Rose-Krasnor, L., Rubin, K. H., Booth, C. L., \& Coplan, R. (1996). The Relation of Maternal Directiveness and Child Attachment Security to Social Competence in Preschoolers. International Journal of Behavioral Development, 19(2), 309-325. https://doi.org/10.1177/016502549601900205

Skelly, S. M., \& Bradley, J. C. (2007). The Growing Phenomenon of School Gardens : Measuring Their Variation and Their Affect on Students ' Sense of Responsibility and Attitudes Toward Science and the Environment. Applied Environmental Education \& Communication, (January 2015), 37-41. https:/ / doi.org/10.1080/15330150701319438

Spingrad TL \& Gal D.E. (2017). Fostering Prococial Behavior and Emphaty in Yong Chilidern. Copsyc, 529. https:// doi.org/10.1016/j.copsyc.2017.08.004

Spinrad, T. L., Eisenberg, N., Gaertner, B., Popp, T., Smith, C. L., Kupfer, A., ... Hofer, C. (2007). Relations of Maternal Socialization and Toddlers ' Effortful Control to Children ' s Adjustment and Social Competence. 43(5), 1170-1186. https://doi.org/10.1037/00121649.43 .5 .1170

Sugiyono. (2019). Metode Penelitian Pendidikan (ke-3 cetak; A. Nuryanto, ed.). Yogyakarta: CV. AlfaBeta.

Vandermaas-peeler, M., \& Mcclain, C. (2015). The green bean has to be longer than your thumb: An observational study of preschoolers ' math and science experiences in a garden. 3(1), 8-27.

Verde, A. et al, \& Valdés, A. (2014). The Journal of Environmental Education Garden-Based Learning: An Experience With " At Risk " Secondary Education Students GardenBased Learning: An Experience With " At Risk " Secondary Education Students. The Journal of Environmental Education, (September 2014), 37-41. https:// doi.org/10.1080/00958964.2013.786669

Williams, D. R., \& Dixon, P. S. (2013). Impact of Garden-Based Learning on Academic Outcomes in Schools: Synthesis of Research Between 1990 and 2010. 83(2), 211-235. https:// doi.org/10.3102/0034654313475824

Williams, D., States, U., \& Anderson, J. (2015). Tongue-Tied No More : Diversity Pedagogy and Sense of Place in the Learning Gardens. Canadian Journal of Environmental Education, 25-45. 